University of Nebraska - Lincoln

DigitalCommons@University of Nebraska - Lincoln

Educational Psychology Papers and

Publications

Educational Psychology, Department of

1991

Universals, Necessities, and Social Contexts

David Moshman

University of Nebraska-Lincoln, dmoshman1@unl.edu

Follow this and additional works at: https://digitalcommons.unl.edu/edpsychpapers

Part of the Educational Psychology Commons

Moshman, David, "Universals, Necessities, and Social Contexts" (1991). Educational Psychology Papers and Publications. 88.

https://digitalcommons.unl.edu/edpsychpapers/88

This Article is brought to you for free and open access by the Educational Psychology, Department of at DigitalCommons@University of Nebraska - Lincoln. It has been accepted for inclusion in Educational Psychology Papers and Publications by an authorized administrator of DigitalCommons@University of Nebraska - Lincoln. 


\title{
Universals, Necessities, and Social Contexts
}

\author{
David Moshman, Educational Psychology, \\ University of Nebraska-Lincoln, Lincoln, Nebraska 68588-0641
}

\begin{abstract}
Elbers* does an excellent job of integrating, analyzing, and extending recent theoretical and empirical work concerning the relation of learning and development. The purpose of this commentary is to challenge Elbers to address the difficult question of universal sequences in human development. In order to focus the issue, a specific sequence in the development of logical reasoning is proposed.
\end{abstract}

Keywords: development, interactionism, logic, necessity, reasoning

Among psychologists and others interested in human learning, cognition, development, and education, there has been a major and longstanding division between those who see knowledge as a structure actively constructed by the individual mind (and education thus as the facilitation of such internally driven construction) and those who see knowledge as information and skills internalized from the environment (and education thus as a process of active transmission from teacher to learner). With the rise of information-processing, Vygotskian, and neoPiagetian perspectives, this division has been somewhat muted by increasing recognition that knowledge emerges from a complex interaction of internal and external forces, that person and environment both play active roles in learning and development, and that simplistic views of purely individual construction or direct environmental transmission cannot possibly be adequate.

Unfortunately, it is much easier to come up with appealing interactionist rhetoric than to produce specific, testable theories that are genuinely interactionist. Most attempts to construct interactionist theories end up producing theories that are either basically Piagetian with a nod toward the importance of environmental factors or basically environmen-

* Ed Elbers, "The Development of Competence and Its Social Context," Educational Psychology Review 3:2 (1991), pp. 73-94; the article upon which the present essay is a comment. 
talist with a nod toward the active nature of the mind. Despite the most earnest efforts of numerous highly competent psychologists, fully interactionist theories have been surprisingly difficult to produce.

There are, however, some ongoing efforts that hold real promise with respect to genuinely transcending the traditional dichotomies of active mind vs. active environment, individual vs. society, construction vs. transmission, development vs. learning, etc. Elbers does an excellent job of summarizing, integrating, criticizing, and extending this work. He not only performs a major service in presenting some important current trends and debates within developmental psychology to a broader audience interested in education, but manages simultaneously to make a significant contribution to the ongoing efforts in this area.

There is nothing in the article that I particularly disagree with. I do wonder, however, how Elbers would extend his perspective to address some other issues. I would like to direct my commentary, then, to raising a set of difficult issues that I would like to see Elbers address.

At the core of the issues I have in mind is the universality of developmental sequences. Piagetian theories generally propose that certain sequences of development are universal because they lead naturally to higher levels of equilibrium (or adequacy, or something of that sort). Such a claim is at odds with the socialization view that development is fundamentally relative to culture.

Where would an interactionist stand on this? I think this is the point at which interactionists generally show their true colors, revealing themselves to be, at heart, either developmentalists or environmentalists.

To the extent that a particular interactionist view is really developmental at its core, its proponents would probably maintain that certain sequences are universal in the sense that each step must precede the next and can only be followed by the next. This is not to deny that interaction with the environment is necessary for development to occur and that the nature of the environment may substantially facilitate or hinder development. The point is that, regardless of one's social context, one must reach stage 2 of a given sequence before one can proceed to stage 3 , and if one moves beyond stage 2 it can only be to stage 3 . There is a natural progression toward greater equilibrium (or truth, or self-reflection, or rationality, or whatever) that results in a sequence that is universal regardless of the language, culture, or point of view underlying one's socialization.

To the extent that a particular interactionist view is really environmentalist at its core, on the other hand, its proponents would likely maintain that what gets constructed depends on the environment with which one interacts. This is not to deny that knowledge is actively constructed by 
the mind rather than internalized from the environment. The point is that the direction of development (not merely its rate) is relative to social context. There are no sequences that must be followed. Behavior and knowledge are entirely a function of language, culture, or viewpoint.

I think we can readily agree that many important behavioral changes are a function of social context and that knowledge is at least in part relative to language, culture, and point of view. The question is whether there are any universals or necessities.

Having come this far, I might as well go right to the edge of the precipice: Let me propose a specific sequence and claim that it is universal (see Moshman, 1990; Moshman and Lukin, 1989). Fairly young infants show behavior that corresponds to certain logical norms (Langer, 1980). Consider, for example, an infant who knows that an object is under the chair or the couch, fails to find it under the chair, and then immediately looks under the couch. Such an infant is behaving in accord with the disjunctive scheme $p$ or $q$; not- $p$; therefore, $q$. Preschool children respond to verbal problems in ways that suggest a similar application of implicit inference schemes (Hawkins et al., 1984). Moreover, there is reason to think that such inference schemes reflect underlying logical necessities that are not entirely relative to language or culture (see Braine and Rumain, 1983, for a plausible set of such schemes). We may therefore suggest that normal human beings in any culture will progress from the sensorimotor application of certain inference schemes that are largely the same in any culture to (stage 2) application of such schemes at a level of representational cognition.

We can even take this further. There is evidence that beginning about age 5 or 6 children show sufficient metacognitive reflection on their own inferences to recognize inference as a distinct source of knowledge (Sodian and Wimmer, 1987) and to distinguish logical necessities from mere conventions or empirical regularities (Somerville et al., 1979). Cultures may differ in what proportion of individuals achieve this third stage and at what age they achieve it, but I doubt if they differ with respect to the fundamental nature of this third stage (i.e., in what inferences are identified as logically necessary). Moreover, there is evidence that, beginning about age 11 or 12, at least some individuals in some cultures achieve a fourth stage at which they can understand the validity of formal arguments independent of their content (Moshman and Franks, 1986). Thus, for example, they understand that if elephants are animals or plants, and elephants are not animals, then elephants are plants.

What will Elbers say about all this? No doubt he will insist that making a proper inference involves recognizing when such an inference is called for and may, in complex tasks, require strategies for application 
of one's logical knowledge. Moreover, such utilization and procedural competencies may be taught and such teaching may play an important role in the development of basic logical principles. Furthermore, various cultures may differ dramatically in the extent to which they encourage and support logical reasoning. Individuals in some cultures may develop much more rapidly than individuals in other cultures. There may be some cultures where development beyond the second or third of the above stages is rare or nonexistent. I happily grant all of this.

So where does that leave us? If Elbers is willing to acknowledge that some deductive inferences are logically necessary, that others are fallacious, and that development naturally moves toward increasingly appropriate inference schemes and increasingly abstract metacognitive reflection on the formal properties of such schemes, then I think his view is essentially developmental. This leaves plenty of room for specific socialization experiences and broader cultural contexts to influence development but still acknowledges cross-cultural universals and necessities.

If, on the other hand, Elbers maintains that the logic one constructs is entirely a function of one's language, culture, and/or socialization experiences and that there is thus no natural, universal route in the development of logical reasoning, then I think his view is essentially environmentalist. This leaves plenty of room for active construction by the individual but accords the environment the power not merely to facilitate the development of logical reasoning but to actively determine its course.

There may, of course, be other possibilities, or even radically different ways of framing the issue. I'm really not sure, on the basis of his article, what Elbers will say about all this. I hope the readers of this exchange are as curious as I am to find out.

\section{References}

Braine, M. D. S., and Rumain, B. (1983). Logical reasoning. In Flavell, J. H., and Markman, E. M. (eds.), P. H. Mussen (series ed.). Handbook of Child Psychology: Vol. 3, Cognitive Development (Wiley, New York), pp. 263-340.

Hawkins, J., Pea, R. D., Click, J., and Scribner, S. (1984). “Merds that laugh don't like mushrooms": Evidence for deductive reasoning by preschoolers. Developmental Psychology 20: 584-594.

Langer, J. (1980). The Origins of Logic: Six to Twelve Months (Academic Press, New York).

Moshman, D. (1990). The development of metalogical understanding. In Overton, W. F. (ed.), Reasoning, Necessity, and Logic (Erlbaum, Hillsdale, New Jersey).

Moshman, D., and Franks, B. A. (1986). Development of the concept of inferential validity. Child Development 57: 153-165. 
Moshman, D., and Lukin, L. E. (1989). The creative construction of rationality: A paradox? In Glover, J. A., Ronning, R. R., and Reynolds, C. R. (eds.). Handbook of Creativity (Plenum, New York).

Sodian, B., and Wimmer, H. (1987). Children's understanding of inference as a source of knowledge. Child Development 58: 424-433.

Somerville, S. C., Hadkinson, B. A., and Greenberg, C. (1979). Two levels of inferential behavior in young children. Child Development 50: 119-131. 